\title{
Sintonia espaço-tempo
}

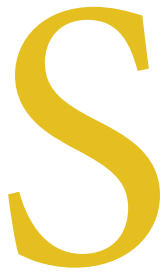

e a informação jornalística é a informação organizada periodicamente e sistematizada no tempo, podemos aceitar a noção de que o Jornalismo, como produção dos veículos de comunicação, tem como função social contribuir para a compreensão do mundo. Esta visão crítica e este papel educativo devem estender-se à pesquisa sobre o Jornalismo. Espaço e tempo devem ser preocupações fundamentais tanto no fazer jornalismo como no pensar sobre o Jornalismo. A atualidade, seja imediata ou contemporânea, ou a proximidade, podem ser critérios tanto para a pauta como para o projeto de pesquisa. Esta linha de raciocínio nos leva a enaltecer a importância de a academia lançar seu olhar para as questões emergentes.

Em 2016, o país vivenciou um fenômeno político e midiático por conta dos movimentos de ocupação de estabelecimentos de ensino. Veio à tona o protagonismo de crianças e jovens em defesa de várias bandeiras como as melhorias das condições de ensino e contra reformas que consideravam prejudiciais à Educação. $\mathrm{O}$ artigo que abre esta edição, de autoria de Beatriz Becker e sua equipe composta por Igor Waltz, Rafael Pereira da Silva e Giovanni Codeça, aborda essa questão. A partir de um estudo comparativo de conteúdos e formatos audiovisuais produzidos pelos estudantes e de reportagens de telejornais locais este artigo discute como esse acontecimento foi construído no ambiente midiático e identifica tendências atuais de enunciação de narrativas jornalísticas audiovisuais decorrentes da hibridização de linguagens e formatos nas telas do computador e da televisão.

Com a mesma inquietação de tratar dos temas contemporâneos, como também buscar o papel educativo do Jornalismo, Karina Gomes Barbosa e André Luís Carvalho analisam as estratégias narrativas empregadas pelo jornalismo laboratorial universitário marianense para construir uma narrativa do trauma nas páginas do jornal Lampião. Ali, procuram perceber como o veículo materializa a experiência do rompimento da barragem do Fundão, pertencente à Samarco, em Mariana (MG), evento traumático das coletividades locais.

Além da importância de o Jornalismo tratar temas emergentes contemporâneos, outra questão que perpassa esta necessária tematização é a questão da midiatização das práticas sociais. Cada vez mais, pessoas e instituições dispõem dos recursos midiáticos necessários para produzir informações e conteúdos diversos. Com isso, o jornalismo necessita buscar alternativas para manter e/ou alcançar a sua legitimação institucional. Essas questões são tratadas por Carolina Teixeira Weber Dall Agnese, Eugenia Maria Mariano da Rocha Barichello e Vivian de Carvalho Belochio em artigo 
que reflete a respeito dos processos de legitimação institucional do Jornalismo no âmbito da produção noticiosa hipermídia, a partir da análise de estratégias de autorreferencialidade verificadas no discurso e na configuração de uma grande reportagem multimídia (GRM) do webjornal The Guardian. De modo semelhante, Clarissa Corrêa Henning apresenta uma reflexão sobre a credibilidade jornalística no contexto da cibercultura, em que muitos internautas que produzem conteúdo informativo colocam em risco a legitimidade jornalística.

Da relação entre aquilo que a sociedade manifesta e reivindica de informações e conteúdos por meio das diversas mídias e aquilo que o Jornalismo enquanto instituição social diz ser, narrar e fazer pelo interesse da coletividade há alguns silenciamentos por parte deste último. Esta (des)coberta do jornalismo público é tratado por Patrícia Milano Pérsigo, ao investigar os silêncios percebidos em práticas do jornal Zero Hora. Dentre a complexidade de questóes que podem silenciar o jornalismo público, como constrangimentos organizacionais, controle editorial, a busca pela audiência/anunciantes, o enxugamento das redações, a precarização e desvalorização do trabalho jornalístico, há uma questão sutil, porém decisiva, que é a construção narrativa adotada pela linguagem jornalística. Neste sentido, uma das formas alternativas de narrar aspectos importantes da vida cotidiana e que muitas vezes são silenciados pela mídia hegemônica é por meio da grande reportagem, questão tratada por José Augusto Mendes Lobato, ao analisar a configuração do gênero, pressupostos, funções e correntes.

Todos os trabalhos referidos acima constituem o núcleo temático "MUTAÇÕES E DESAFIOS NO JORNALISMO: tecnologias, legitimidade e narratividade". Na sequência, este tema central é tangenciado com trabalhos que questionam as escolhas de pesquisadores, profissionais do jornalismo e práticas de ensino que são decisivas para compreender de modo mais claro como o Jornalismo poderá enfrentar essas transformações contemporâneas que estão questionando suas práticas, seus processos e sua legitimidade: Luana Meneguelli Bonone descreve e problematiza a respeito da metodologia de enquadramento (Frame Analysis), tendo como referência a dissertação "Privatizando a opinião: um estudo sobre enquadramento nas revistas Veja e Carta Capital"; Rafael Bellan Rodrigues de Souza propõe uma "práxis noticiosa realista", a partir da relação entre a teoria de Adelmo Genro Filho e a estética de György Lukács, que possibilita potencializar o conhecimento produzido pelo jornalismo; Debora Cristina Lopez, Kamilla Morando Avelar e Luana Viana e Silva demonstram a compreensão sobre o posicionamento das webradios de universidades federais que contam com cursos de jornalismo na região Sul do Brasil, considerando o cenário da convergência a partir da inserção dessas webradios nos cursos de jornalismo.

$$
\text { *** }
$$

Ainda fazendo analogias sobre o fazer e o pensar o Jornalismo, temos o critério da relevância. Mas o contrário da relevância para o Jornalismo não é necessariamente a irrelevância. Por uma lógica estranha, nota-se a "não-presença" ou o "silenciamento" de temas na Imprensa - e na pesquisa sobre o Jornalismo. Este é um dos pontos evidenciados por Cláudia Lago, em entrevista concedida aos doutorandos Janara Nicoletti e William Robson Cordeiro para a EJM. Durante a realização do $14^{\circ}$ Encontro Nacional de Pesquisadores em Jornalismo, realizado em Palhoça/SC, a presidente do SBPJor argumentou que questões de gênero e étnico-raciais são pouco exploradas 
nas pesquisas em Jornalismo e apresentam um grande potencial para o campo. Além de tratar desses silenciamentos, Cláudia Lago discorreu sobre a cultura que se estabeleceu no campo da pesquisa no Brasil, com a pouca tradição da pesquisa empírica e da pesquisa aplicada, como também sobre os esforços para se construir redes de pesquisa. Estes e outros temas são tratados nessa entrevista, através da qual a EJM procura revitalizar esse espaço que também é importante para a reflexão sobre nossa área.

Esta edição da EJM é completada com a resenha "É preciso pensar a crise do Jornalismo", elaborada por Liliane de Lucena Ito, que apresenta várias questões decorrentes das mutações e desafios contemporâneos enfrentados pelo Jornalismo, e abordadas no livro Questões Para um Jornalismo em Crise (Editora Insular), publicado pelo Programa de Pós-Graduação em Jornalismo da Universidade Federal de Santa
Catarina e organizado pelo professor Rogério Christofoletti.

Por fim, esta edição com núcleo temático sobre mutações e desafios do Jornalismo também trata das mudanças e enfrentamentos decorrentes de dois processos de "transição" editorial que a revista passou em 2016. Após coordenar a EJM por vários anos, Rogério Christofoletti "passou o bastão" às mãos da colega Cárlida Emerim, que responsabilizou-se pela produção da edição 2016-1. Com o afastamento de Cárlida para qualificação em pós-doutorado, coube a nós prosseguir com este honroso desafio. Desde já, agradecemos a prestimosa colaboração e imensa atenção da equipe de avaliadores e de revisores desta edição.

Boa leitura!

Jorge Kanehide Ijuim

Daiane Bertasso Ribeiro 